\title{
AKSES PENYANDANG DISABILITAS TERHADAP LAYANAN DAN FASILITAS TRANSPORTASI PUBLIK DI KOTA BANDA ACEH
}

\author{
Putra Rizkiya $^{1}$, Myna Agustina Yusuf ${ }^{2}$, Irin Caisarina ${ }^{3}$ \\ ${ }^{1}$ Fakultas Teknik, Universitas Syiah Kuala, email: putrarizkiya@unsyiah.ac.id \\ ${ }^{2}$ Fakultas Teknik, Universitas Syiah Kuala, email: mynayusuf@unsyiah.ac.id \\ ${ }^{3}$ Fakultas Teknik, Universitas Syiah Kuala, email: irincaisarina@unsyiah.ac.id
}

\begin{abstract}
ABSTRAK
Terwujudnya kota inklusif merupakan salah satu tujuan global dalam Sustainable Development Goals (SDGs) 2015-2030. Kota inklusifmerupakan sebuah prinsip untuk menciptakan ruang kota yang ramah bagi semua kalangan termasuk penyandang disabilitas, yang merupakan salah satu kelompok marginal di perkotaan. Kota Banda Aceh telah melakukan berbagai upaya untuk mencapai kota inklusif namun masih memerlukan peningkatan signifikan dalam berbagai bidang, termasuk transportasi. Isu transportasi memegang peranan krusial karena transportasi mempengaruhi mobilitas dan integrasi warga dalam ruang kota. Penelitian ini bertujuan untuk menilai akses penyandang disabilitas terhadap pelayanan dan fasilitas transportasi publik khususnya dalam transportasi publik kota yaitu Trans Kutaraja dan jalur pedestrian. Data dikumpulkan melalui pengisian instrumen tingkat akses penyandang disabilitas terhadap layanan dan fasilitas transportasi yang diikuti dengan wawancara dengan perwakilan dari organisasi penyandang disabilitas. Metode analisis yang digunakan adalah deskriptif kualitatif. Hasil penelitian menunjukkan bahwa penyandang disabilitas menilai akses ke pelayanan transportasi publik Trans Kutaraja dan jalur pedestrian masih kurang baik. Kondisi ini diakibatkan oleh kurang baiknya penerapan desain universal dan fasilitas akomodasi yang layak di halte dan jalur pedestrian yang belum ramah penyandang disabilitas. Hal ini menyebabkan hambatan fisik sehingga mereka sulit mengakses pelayanan dan fasilitas transportasi. Sulitnya mobilitas menghambat partisipasi penyandang disabilitas dalam kehidupan sehari-hari dan mengakibatkan penyandang disabilitas terasingkan dari ruang kota.
\end{abstract}

Kata kunci: akses, disabilitas, fasilitas, inklusif, transportasi

Info Artikel:

Dikirim: 29 Maret 2021; Revisi: 28 April 2021; Diterima: 29 April 2021; Diterbitkan: 29 April 2021

(C2021 The Author(s). Published by Arsitekno, Architecture Program, Universitas Malikussaleh, Aceh, Indonesia under the Creative Commons Attribution 4.0 International License (https://creativecommons.org/licenses/by/4.0/).

\section{PENDAHULUAN}

Pada tahun 2015, negara-negara di dunia menyepakati sebuah tujuan global baru untuk jangka waktu 2015-2030 yang dikenal sebagai Sustainable Development Goals (SDGs), yang melanjutkan Millenium Development Goals (MDG's) 2000-2015. Salah satu tujuan global dalam SDGs adalah kota inklusif. Kota inklusif merupakan kota yang menciptakan lingkungan yang aman dan layak huni dengan akses yang terjangkau dan setara terhadap layanan perkotaan, layanan sosial dan kesempatan bekerja bagi seluruh warga kota dan pengguna layanan kota yang mempromosikan pembangunan sumber daya manusia yang optimal dan memastikan rasa respek terhadap martabat manusia dan kesetaraan[1].

Konsep kota inklusif muncul sebagai respon dari perubahan paradigma dalam memahami kelompok marginal dan kelompok masyarakat yang kurang beruntung (the most disadvantaged group), seperti kelompok miskin dan kelompok penyandang disabilitas. Namun, penyandang disabilitas sering menjadi fokus utama karena kelompok ini rentan menghadapi berbagai macam hambatan dan memerlukan upaya yang lebih keras dalam menghadapi hambatan tersebut. Hak kaum difabel/ penyandang disabilitas sering diacuhkan[2]. Kelompok penyandang disabilitas 
cenderung mengalami berbagai hambatan partisipasi dalam masyarakat, baik berupa alienasi, segregasi dan marginalisasi dari perspektif sosial-budaya. Sementara dalam konteks infrastruktur kota, penyandang disabilitas mengalami hambatan dalam bentuk aksesibilitas yang terbatas terhadap layanan infrastruktur kota seperti sulitnya akses terhadap fasilitas dan layanan transportasi publik.

Saat ini konsep kota inklusif semakin mendapatkan perhatian dari pemerintah daerah di Indonesia. Sejak 2013, telah ada beberapa kota di Indonesia yang mencanangkan diri menjadi kota inklusif antara lain Surakarta, Yogyakarta, Padang, Brebes dan Jember[3]. Namun, banyak penelitian di Indonesia yang mengungkapkan tentang masih rendahnya aksesibilitas fasilitas publik bagi penyandang disabilitas. Penelitian di Kota Malang misalnya menemukan bahwa hampir seluruh fasilitas publik di kota tersebut tidak bisa diakses disabilitas[4].

Pemerintah Kota Banda Aceh, Aceh, merupakan salah satu kota di Indonesia yang telah mulai melihat pentingnya penerapan konsep kota inklusif dalam pembangunan kota. Pada 2017, Walikota Banda Aceh mengeluarkan Peraturan Walikota Nomor 14 Tahun 2017 tentang Perencanaan Pembangunan Inklusif. Di beberapa fasilitas publik di Banda Aceh, telah ada upaya untuk menerapkan desain universal yang mengakomodasi kebutuhan penyandang disabilitas, misalnya pada halte sistem angkutan bus Transkutaraja, fasilitas kesehatan, pendidikan dan kantor pemerintah.

Upaya ini patut diapresiasi, namun penerapannya masih perlu ditingkatkan. Saat ini fasilitas dan pelayanan publik di Banda Aceh masih jarang sekali digunakan penyandang disabilitas karena berbagai hambatan dalam menjalankan aktivitas sehari-hari. Salah satu faktor penghambat partisipasi penyandang disabilitas di Kota Banda Aceh adalah belum ramahnya sistem pelayanan transportasi publik dan fasilitas penunjangnya bagi kelompok penyandang disabilitas seperti jalur pedestrian. Akses transportasi yang sulit menghambat mobilitas penyandang disabilitas sehingga kelompok ini jarang berpartisipasi dalam aktivitas kota sehari-hari seperti berbelanja, berekreasi, dan berolahraga. Hal ini menunjukkan bahwa kebijakan pemerintah terhadap para penyandang disabilitas dalam transportasi sangat menentukan partisipasi penyandang disabilitas dalam ruang kota. Transportasi yang aman, efisien dan dapat diakses oleh semua kalangan adalah komponen kunci dari integrasi masyarakat[5].

Penelitian ini bertujuan untuk mengukur penilaian kelompok penyandang disabilitas terkait akses mereka terhadap layanan transportasi di Kota Banda Aceh. Penelitian ini diharapkan bisa memberikan input dalam upaya meningkatkan kualitas pelayanan transportasi untuk mencapai pelayanan transportasi yang inklusif bagi semua kalangan termasuk penyandang disabilitas di Kota Banda Aceh. Dengan demikian, dapat tercipta sebuah kota yang lebih berkelanjutan dan lebih ramah bagi semua kalangan.

\section{Disabilitas dan Kota Inklusif}

Konsep kota inklusif pada dasarnya bertujuan untuk menciptakan lingkungan kota yang bisa diakses oleh seluruh warga kota secara setara, baik dari segi pelayanan perkotaan, interaksi sosial dan kesempatan ekonomi. Dengan demikian, prinsip ini dibangun atas dasar respek pada martabat manusia dan prinsip kesetaraan bagi seluruh warga kota, termasuk bagi kelompok marginal. Oleh karena itu, inklusifitas sebuah kota pada dasarnya bisa dinilai berdasarkan akses warga kota ke layanan dan fasilitas publik seperti layanan tenaga kerja, perumahan, transportasi, taman, tempat rekreasi dan lain-lain. Hal ini juga perlu diikuti dengan upaya-upaya perlindungan terhadap hak dan partisipasi warga.

Lahirnya konsep kota inklusif tidak terlepas dari permasalahan terhambatnya partisipasi kelompok-kelompok marginal dalam kehidupan masyarakat. Hal ini menimbulkan eksklusi sosial. Eksklusi sosial merupakan sebuah kondisi yang menghambat individu atau kelompok tertentu dalam berpartisipasi dalam masyarakat[6]. Eksklusi sosial merupakan sebuah proses yang multidimensional dan dinamis yang menghalangi akses individu dan kelompok terhadap kesempatan ekonomi, pembangunan manusia dan partisipasi sosial. Hal ini juga menghambat integrasi sosial seseorang dalam masyarakat. Individu atau kelompok yang mengalami eksklusi sosial berada di suatu tempat namun tidak bisa beraktivitas dan berpartisipasi layaknya warga lain. Bentuk eksklusi sosial ini bisa berupa diskriminasi, alienasi (pengasingan), dan marginalisasi (terpinggirkan). Terbatasnya partisipasi ini tidak terlepas dari hambatan-hambatan dalam 
masyarakat. Untuk itu, perlu ada perubahan sosial dalam masyarakat dalam memandang disabilitas.

Saat ini penerapan kota inklusif telah mengalami perubahan paradigma dari paradigma tradisional yang melihat penyandang disabilitas sebagai objek menuju paradigma inklusi sosial, sebuah model yang mana mendorong pelibatan penyandang disabilitas dalam kehidupan bermasyarakat[7]. Saat ini pandangan akan pentingnya partisipasi sosial dalam kebijakan terkait penyandang disabilitas semakin meningkat [8].

Disabilitas merupakan bagian dari hidup manusia. Contohnya yaitu orang yang sudah memasuki usia lanjut mengalami penurunan dalam berfungsinya bagian tubuh tertentu, misalnya pada indra pendengaran dan penglihatan. Contoh lain yaitu orang yang tidak bisa berjalan sementara pasca kecelakaan. Jadi, pada dasarnya hampir semua orang mengalami disabilitas baik secara permenan maupun sementara dalam suatu fase dalam hidupnya[9]. Namun, hambatan dan kesukaran yang dialami akibat disabilitas bisa berbeda.

Penyandang disabilitas cenderung memiliki hambatan yang lebih berat untuk mendapatkan hak-haknya karena banyaknya hambatan yang dihadapi. World Health Organization (WHO) mendefinisikan barriers/ hambatan sebagai faktor dalam lingkungan seseorang yang akibat ada atau tidak adanya tersebut menyebabkan terhambatnya fungsi (functioning) dan menciptakan disabilitas (disability), misalnya fasilitas yang tidak diakses, fasilitas akomodasi yang kurang serta pandangan negatif kepada penyandang disabilitas[10]. Fungsi dalam hal ini mencakup fungsi-fungsi tubuh, aktivitas, dan partisipasi. Istilah functioning menunjukkan kondisi manusia biasa yang tubuhnya berfungsi, beraktivitas dan berpartisipasi secara maksimal. Sementara disabilitas adalah sebuah istilah yang mencakup adanya kekurangan fisik, terbatasnya aktivitas serta terhalangnya partisipasi. Disabilitas ini bisa disebabkan oleh faktor fungsi tubuh, struktur tubuh, aktivitas dan partisipasi serta faktor lingkungan tertentu seperti sikap anti sosial. Disabilitas menciptakan hambatan yang menyulitkan bagi penyandangnya.

Hambatan yang dialami oleh kelompok penyandang disabilitas juga tidak terlepas dari pandangan masyarakat yang terlihat dari munculnya stigma dalam masyarakat sehingga menimbulkan pandangan negatif dan menimbulkan diskriminasi bagi penyandang disabilitas. Pencapaian kota inklusif dan ramah bagi penyandang disabilitas sangat ditentukan oleh akses penyandang disabilitas terhadap layanan infrastruktur dan fasilitas publik. Aksesibilitas yang setara bagi semua kalangan memegang peranan penting dalam mencapai kota yang inklusif.

\section{Akses Penyandang Disabilitas ke Layanan Transportasi Publik}

Akses transportasi merupakan bagian dari hak penyandang disabilitas dalam pelayanan publik. Undang-Undang Republik Indonesia Nomor 8 Tahun 2016 tentang Penyandang Disabilitas menyebut bahwa hak pelayanan publik tersebut meliputi hak: a) memperoleh akomodasi yang layak dalam pelayanan publik secara optimal, wajar, bermartabat tanpa diskriminasi dan b) pendampingan, penerjemahan, dan penyediaan fasilitas yang mudah diakses di tempat layanan publik tanpa tambahan biaya. Agar dapat dimanfaatkan penyandang disabilitas dengan maksimal, maka sistem pelayanan transportasi publik perlu dilengkapi dengan akomodasi yang layak serta penyediaan fasilitas yang mudah diakses serta diikuti dengan pendampingan dan penerjemahan.

Pemerintah Pusat dan Pemerintah Daerah wajib menyediakan pelayanan publik yang mudah diakses oleh penyandang disabilitas, termasuk dalam sektor transportasi. Pelayanan publik yang mudah diakses juga wajib disebarluaskan dan disosialisasikan pada penyandang disabilitas dan masyarakat. Selain itu, penyelenggara pelayanan publik wajib menyediakan panduan pelayanan publik yang mudah diakses oleh penyandang disabilitas. Akses transportasi ini termasuk akses transportasi darat, kereta api, laut dan udara.

Akses ke layanan transportasi publik sangat dipengaruhi oleh akses ke sistem layanan serta fasilitas penunjangnya. Akses ini mencakup akses ke sarana transportasi seperti halte, akses secara ekonomi (kemampuan membayar) serta akses ke fasilitas penunjang, yaitu jalur pedestrian.

Permasalahan yang akan dijawab dalam penelitian ini adalah bagaimana penilaian penyandang disabilitas terhadap akses layanan fasilitas dan infrastruktur transportasi di Kota Banda Aceh? Penelitian ini bertujuan untuk menilai akses penyandang disabilitas terhadap 
fasilitas dan layanan transportasi publik di Banda Aceh. Diharapkan, hasil studi ini dapat dijadikan salah satu acuan dalam perencanaan pembangunan inklusif di Kota Banda Aceh, terutama di bidang transportasi.

\section{METODE PENELITIAN}

Penelitian ini mengukur penilaian kelompok penyandang disabilitas terhadap infrastruktur dan pelayanan transportasi publik di Kota Banda Aceh. Penilaian ini akan diukur dari penilaian aksesibilitas penyandang disabilitas terhadap sistem layanan angkutan publik Transkutaraja dan fasilitas penunjangnya yaitu jalur pedestrian. Jalur pedestrian menjadi fokus karena memegang peranan penting dalam mobilitas warga termasuk penyandang disabilitas menuju halte, yang merupakan pintu masuk ke sistem layanan transportasi publik.

Penelitian ini menggunakan metode deskriptif kualitatif. Pengumpulan data dilakukan dengan membagikan instrumen penilaian tingkat aksesibilitas penyandang disabilitas terhadap layanan dan fasilitas transportasi publik. Transportasi publik di Kota Banda Aceh diselenggarakan oleh publik dan swasta. Sistem transportasi publik diselenggarakan melalui operasionalisasi sistem angkutan publik Transkutaraja. Sementara itu, transportasi umum oleh swasta diadakan melalui layanan labi-labi, becak, taksi dan angkutan online. Namun, studi ini hanya akan fokus pada pelayanan sistem angkutan publik Transkutaraja.

Dalam pemilihan narasumber, peneliti terlebih dahulu menghubungi organisasi Perkumpulan Penyandang Disabilitas Indonesia (PPDI) Aceh. Narasumber yang dipilih merupakan rekomendasi dari PPDI Aceh dengan mempertimbangkan keaktifan mereka selama ini dalam kegiatan dan diskusi internal PPDI Aceh serta dalam diskusi dengan pihak eksternal seperti pemerintah dan lembaga swadaya masyarakat. Pengisian instrumen ini dilakukan oleh lima orang narasumber sebagai perwakilan dari organisasi-organisasi penyandang disabilitas di Kota Banda Aceh. Pengisian instrumen ini juga diikuti dengan wawancara untuk menggali alasan yang melatarbelakangi pemberian nilai yang dipilih. Perwakilan-perwakilan narasumber mengisi instrumen ini bersama dan memberi nilai setelah berdiskusi bersama dalam forum diskusi terbatas sehingga peneliti bisa mendapatkan informasi yang mendalam terkait isu-isu yang dibahas.

Tabel 1. Instrumen Penilaian Akses Penyandang Disabilitas Terhadap Layanan dan Fasilitas Transportasi Publik di Kota Banda Aceh

\begin{tabular}{cllccc}
\hline No & Kriteria & \multicolumn{1}{c}{ Penjelasan } & Ya & Klasifikasi \\
\hline $\mathbf{1}$ & Ketersediaan & Tersedia & 1 & Kurang Baik \\
$\mathbf{2}$ & Aksesibilitas & $\begin{array}{l}\text { Memenuhi standar minimum } \\
\text { Dapat didatangi/ diakses penyandang disabilitas } \\
\text { Dapat didatangi/ didapatkan penyandang } \\
\text { disabilitas dan pulang dengan lancar }\end{array}$ & 3 & \\
& & 4 & \\
$\mathbf{3}$ & Akomodasi & $\begin{array}{l}\text { Mengakomodasi kebutuhan disabilitas dibayar/ } \\
\mathbf{4}\end{array}$ & Keterjangkauan & $\begin{array}{l}\text { Layanan/ infrastruktur mampu diban } \\
\text { dimanfaatkan oleh disabilitas }\end{array}$ & Sedang \\
$\mathbf{5}$ & Penerimaan & Bisa digunakan dan diterima oleh disabilitas & 7 & Baik \\
\hline
\end{tabular}

Sumber: Dimodifikasi dari [11]

\section{HASIL DAN PEMBAHASAN}

Pembahasan terkait tingkat akses penyandang disabilitas terhadap pelayanan transportasi akan dibagi menjadi dua bagian yaitu akses terhadap pelayanan transportasi publik dan akses terhadap jalur pedestrian.

\section{Akses Terhadap Transportasi Publik}

Secara umum, kelompok disabilitas menilai bahwa pelayanan transportasi bagi kelompok disabilitas di Kota Banda Aceh masih kurang baik karena sulit diakses. Sulitnya aksesibilitas ke sistem pelayanan Trans Kutaraja antara lain dapat dilihat dari rancangan halte yang belum ramah disabilitas. Di banyak halte yang tersedia, ramp halte masih curam sehingga sulit digunakan penyandang disabilitas pengguna kursi roda. Halte dengan ramp yang curam merupakan imbas dari penggunaan Bus Transkutaraja yang bertipe high-deck. Untuk menaiki ramp ini, mereka 
masih membutuhkan bantuan dari pihak lain. Penyandang tuna netra juga sulit mengakses halte karena banyak halte belum memiliki guiding block. Penyandang disabilitas menilai sulit sekali bagi mereka untuk mengakses halte yang merupakan titik masuk ke layanan Transkutaraja akibat kurangnya fasilitas akomodasi yang layak bagi disabilitas. Hal ini menunjukkan bahwa secara umum penerapan desain universal di halte belum maksimal.

Keberadaan halte portable di beberapa titik juga menyulitkan kelompok disabilitas. Hal ini menunjukkan bahwa ada hambatan fisikal bagi penyandang disabilitas untuk sistem transportasi publik Transkutaraja. Hasil penilaian ditampilkan dalam tabel berikut:

Tabel 2. Akses Penyandang Disabilitas Terhadap Layanan Transportasi Publik Transkutaraja

\begin{tabular}{|c|c|c|c|c|}
\hline No & Kriteria & Penjelasan & Ya & Klasifikasi \\
\hline \multirow[t]{2}{*}{1} & Ketersediaan & Tersedia & 1 & \multirow[t]{4}{*}{ Kurang Baik } \\
\hline & & Memenuhi standar minimum & 2 & \\
\hline \multirow[t]{2}{*}{2} & Aksesibilitas & Dapat didatangi/ diakses penyandang disabilitas & 3 & \\
\hline & & $\begin{array}{l}\text { Dapat didatangi/ didapatkan penyandang } \\
\text { disabilitas dan pulang dengan lancar }\end{array}$ & 4 & \\
\hline 3 & Akomodasi & Mengakomodasi kebutuhan disabilitas & 5 & \multirow[t]{2}{*}{ Sedang } \\
\hline 4 & Keterjangkauan & $\begin{array}{l}\text { Layanan/ infrastruktur mampu dibayar/ } \\
\text { dimanfaatkan oleh disabilitas }\end{array}$ & 6 & \\
\hline 5 & Penerimaan & Bisa digunakan dan diterima oleh disabilitas & 7 & Baik \\
\hline
\end{tabular}

Berdasarkan argumentasi ini, kelompok disabilitas masih mengkategorikan akses penyandang disabilitas terhadap layanan transportasi publik Trans Kutaraja masih kurang baik. Halte sudah tersedia di keenam koridor Trans Kutaraja dan sebagian sudah memenuhi standar minimum, namun secara umum masih sulit diakses penyandang disabilitas. Fasilitas akomodasi yang wajar yang disediakan juga masih kurang. Biaya Trans Kutaraja masih gratis karena masih mendapat subsidi sehingga terjangkau bagi semua kalangan. Namun karena berbagai hambatan fisik, Trans Kutaraja saat ini masih jarang sekali digunakan oleh penyandang disabilitas.

\section{Akses Terhadap Pedestrian}

Jalur pedestrian merupakan fasilitas penunjang transportasi yang keberadaan dan kualitasnya cukup menentukan dalam menciptakan ruang kota yang ramah-manusia (human friendly). Kualitas pedestrian di ruas-ruas jalan di Banda Aceh telah ditingkatkan dalam beberapa tahun terakhir, terutama di jalan-jalan strategis. Namun, integrasi jaringan jalur pedestrian masih belum maksimal sehingga jumlah pejalan kaki masih sangat terbatas. Jalur pedestrian juga belum terintegrasi dengan pusat-pusat aktivitas utama kota. Hal ini terlihat dari masih adanya kawasan pusat kota yang belum memiliki jalur pedestrian yang representatif, kurangnya shading dan penghijauan serta diperparah oleh iklim mikro kota yang belum nyaman. Hal ini membuat jalur pedestrian di ruang kota secara umum belum ramah bagi pejalan kaki, termasuk penyandang disabilitas. Kondisi ini masih ada di ruas-ruas jalan utama, misalnya di trotoar di Jalan Tgk. Daud Beureuh. Pada ruas jalan ini, fungsi fasilitas jalur pejalan kaki tidak mampu menyediakan keamanan, kenyamanan, keselamatan, kemudahan, kegunaan, kemandirian dan aksesibilitas jalur bagi masyarakat umum apatah lagi kepada penyandang disabilitas[12].

Hambatan yang cukup spesifik bagi penyandang disabilitas dalam mengakses jalur pedestrian adalah adanya penghalang yang biasanya berupa besi di jalur pedestrian. Penghalang ini dibuat untuk menghalangi sepeda motor memasuki jalur pedestrian karena pengguna sepeda motor sesekali memasuki jalur pedestrian karena lengangnya jalur pedestrian. Hal ini merupakan salah satu bentuk kompetisi realistis dalam ruang kota antara pengguna kendaraan dan kelompok pengguna pedestrian, yaitu pejalan kaki yang juga mencakup penyandang disabilitas. Namun kebijakan membuat penghalang ini justru semakin membatasi penyandang disabilitas terutama pengguna kursi roda yang ingin menggunakan jalur pedestrian. Selain itu, jalur pedestrian dan street island yang terlalu tinggi dari jalan membuat penyandang disabilitas sangat sulit menyeberang. Jembatan Penyeberangan Orang (JPO) yang disediakan juga belum mengakomodasi kebutuhan dan sulit sekali digunakan penyandang disabilitas. Misalnya JPO di 
salah satu jalan utama yaitu Jalan Tgk. Daud Beureueh, tidak dapat mengakomodir fasilitas dan akses kepada penyandang disabilitas secara mandiri[13].

Hal ini menunjukkan bahwa jalur pedestrian di Kota Banda Aceh belum mengakomodasi kebutuhan penyandang disabilitas. Jadi, secara umum jalur pedestrian di Banda Aceh dinilai masih belum ramah bagi penyandang disabilitas. Berdasarkan argumentasi di atas, kelompok disabilitas menilai bahwa akses mereka terhadap jalur pedestrian masih kurang baik. Penilaian dari kelompok disabilitas ditampilkan dalam tabel berikut:

Tabel 3. Akses Penyandang Disabilitas Terhadap Jalur Pedestrian

\begin{tabular}{|c|c|c|c|c|}
\hline No & Kriteria & Penjelasan & Ya & Klasifikasi \\
\hline \multirow[t]{2}{*}{1} & Ketersediaan & Tersedia & 1 & \multirow{4}{*}{$\begin{array}{c}\text { Kurang } \\
\text { Baik }\end{array}$} \\
\hline & & Memenuhi standar minimum & 2 & \\
\hline \multirow[t]{2}{*}{2} & Aksesibilitas & Dapat didatangi/ diakses penyandang disabilitas & 3 & \\
\hline & & $\begin{array}{l}\text { Dapat didatangi/ didapatkan penyandang disabilitas } \\
\text { dan pulang dengan lancar }\end{array}$ & 4 & \\
\hline 3 & Akomodasi & Mengakomodasi kebutuhan disabilitas & 5 & \multirow[t]{2}{*}{ Sedang } \\
\hline 4 & Keterjangkauan & $\begin{array}{l}\text { Layanan/ infrastruktur mampu dibayar/ } \\
\text { dimanfaatkan oleh disabilitas }\end{array}$ & 6 & \\
\hline 5 & Penerimaan & Bisa digunakan dan diterima oleh disabilitas & 7 & Baik \\
\hline
\end{tabular}

Kelompok disabilitas menilai bahwa meskipun jalur pedestrian telah dibangun di ruas-ruas jalan utama di Kota Banda Aceh, namun secara umum jalur pedestrian ini belum bisa diakses dan masih banyak yang belum memenuhi standar minimum. Jalur pedestrian yang telah tersedia belum bisa digunakan karena aksesibilitasnya yang belum baik. Selain itu, fasilitas pedestrian yang telah ada juga belum mengakomodasi kebutuhan mereka dengan baik. Fasilitas guiding block telah ada di jalur pedestrian terutama di ruas-ruas jalan utama untuk penyandang disabilitas tuna netra, namun mereka jarang menggunakannya. Jalur pedestrian yang telah dibangun juga belum terintegrasi.

Penjelasan di atas menunjukkan bahwa meskipun upaya peningkatan aksesibilitas bagi penyandang disabilitas di Kota Banda Aceh telah mulai berjalan, penggunaannya belum maksimal. Hal yang sama juga terjadi di banyak kota yang telah mencanangkan program kota inklusif, misalnya di Malang dan Yogyakarta[4], [14].

Hambatan utama bagi penyandang disabilitas dalam layanan transportasi mencakup hambatan fisik dan hambatan kebijakan. Kualitas pedestrian yang masih kurang merupakan imbas dari kebijakan transportasi yang selama ini masih berorientasi pada kendaraan bermotor. Dengan demikian, intervensi yang harus dilakukan mencakup implementasi desain universal dan akomodasi yang layak pada infrastruktur transportasi secara keseluruhan. Selain itu, pemerintah Kota Banda Aceh perlu segera mengadopsi prinsip kota inklusif dalam kebijakan dan perencanaan transportasi dan tata ruang dengan lebih konkrit.

Masih kurang baiknya akses penyandang disabilitas terhadap fasilitas dan layanan transportasi menunjukkan adanya hambatan fisik sehingga membatasi pergerakan penyandang disabilitas. Masih tingginya hambatan membuat penyandang disabilitas di Kota Banda Aceh masih sangat bergantung pada bantuan dari keluarga dan warga lain dalam melakukan pergerakan. Sulitnya mengakses layanan transportasi ini merupakan salah satu penyebab terhalangnya partisipasi penyandang disabilitas dalam interaksi sosial dan aktivitas penduduk kota, termasuk dalam pemanfaatan fasilitas publik lain. Akibatnya, penyandang disabilitas di Kota Banda Aceh saat ini masih mengalami pembatasan aktivitas dan alienasi/terasingkan dalam ruang kota. Kebijakan transportasi dan desain kota yang kurang ramah disabilitas ini lahir dari kurangnya kesadaran akan pentingnya pemenuhan hak bergerak penyandang disabilitas karena penyandang disabilitas jarang melakukan aktivitas di ruang kota. Untuk itu, organisasi penyandang disabilitas perlu meningkatkan kesadarannya akan hak untuk menuntut layanan transportasi yang mengakomodasi kebutuhan mereka.

Peningkatan akses penyandang disabilitas ke layanan transportasi bisa berpengaruh signifikan terhadap peningkatan partisipasi penyandang disabilitas dalam aktivitas fisik, yang mana bisa berdampak lebih jauh pada meningkatnya interaksi sosial dan juga akan meningkatkan partisipasi 
penyandang disabilitas dalam bidang kehidupan yang lain[15]. Penyediaan transportasi yang ramah disabilitas diharapkan bisa menunjang upaya untuk mengintegrasikan penyandang disabilitas ke dalam masyarakat. Peningkatan partisipasi sosial ini juga akan menghilangkan permasalahan terkait eksklusi sosial yang selama ini dialami oleh kelompok penyandang disabilitas dalam kehidupan sehari-hari.

\section{KESIMPULAN DAN SARAN}

Pembahasan di atas menunjukkan bahwa akses penyandang disabilitas terhadap pelayanan transportasi publik dan fasilitas penunjangnya yaitu jalur pedestrian di Kota Banda Aceh masih kurang baik. Meskipun sistem angkutan publik gratis sudah tersedia melalui pelayanan Trans Kutaraja, penyandang disabilitas sulit mengakses pelayanan transportasi publik karena kurangnya penerapan desain universal pada halte serta kurangnya fasilitas akomodasi di halte dan sarana bis.

Penelitian ini juga menunjukkan bahwa jalur pedestrian di Kota Banda Aceh dinilai belum ramah penyandang disabilitas. Meskipun pemerintah telah meningkatkan kualitas jalur pedestrian di sebagian ruas jalan terutama di jalan-jalan utama, secara umum jalur pedestrian belum memiliki kualitas yang baik dan belum terintegrasi dalam suatu jaringan sehingga jumlah pejalan kaki masih sangat terbatas. Beberapa kebijakan spesifik juga merugikan penyandang disabilitas, misalnya pembuatan penghalang sepeda motor di jalur pedestrian yang justru menghambat pengguna kursi roda.

Kurang ramahnya pelayanan dan fasilitas transportasi bagi penyandang disabilitas menghalangi partisipasi penyandang disabilitas dalam kehidupan sehari-hari. Hal ini menyebabkan penyandang disabilitas menjadi salah satu kelompok yang terasingkan dari ruang kota. Untuk itu, diperlukan intervensi agar pelayanan transportasi publik di Kota Banda Aceh lebih inklusif dan ramah disabilitas dengan penerapan desain universal yang lebih baik.

Hasil dari penelitian bisa menjadi input bagi pemerintah kota untuk memenuhi kebutuhan penyandang disabilitas dalam transportasi yang saat ini masih kurang diakomodasi. Pemerintah Kota Banda Aceh perlu memasukkan kebijakan kota inklusif ke dalam dokumen-dokumen perencanaan seperti Rencana Tata Ruang Wilayah (RTRW), Rencana Detail Tata Ruang (RDTR), Rencana Tata Bina Lingkungan (RTBL) dan Tatanan Transportasi Lokal (Tatralok). Masuknya konsep kota inklusif ke dalam dokumen-dokumen perencanaan tata ruang dan transportasi akan membantu penerapan prinsip kota inklusif dalam desain fasilitas-fasilitas kota khususnya fasilitas transportasi.

Salah satu upaya penting dalam mencapai visi kota inklusif adalah dengan menciptakan sistem transportasi yang inklusif bagi penyandang disabilitas. Pemerintah wajib mengakomodasi kebutuhan penyandang disabilitas pada sistem transportasi, baik dalam pelayanan maupun fasilitas penunjangnya khususnya jalur pedestrian. Desain universal dan akomodasi yang wajar khususnya bagi penyandang disabilitas merupakan sebuah urgensi dalam sistem transportasi di perkotaan. Trotoar yang disediakan harus bisa mengakomodasi kebutuhan penyandang disabilitas agar mereka bisa berjalan lancar, mandiri dan tanpa hambatan dengan desain dan material yang layak sesuai standar pelayanan minimum.

Sumber dari penelitian ini merupakan perwakilan dari organisasi penyandang disabilitas sehingga jumlah narasumber yang dilibatkan dalam penelitian ini masih sangat terbatas. Pembatasan narasumber ini bertujuan agar peneliti dapat menggali lebih dalam permasalahan yang dihadapi oleh kelompok disabilitas khususnya dalam layanan transportasi publik. Penelitian ini juga belum melibatkan kelompok dari disabilitas tertentu seperti keterbelakangan mental dan tuna netra karena kesulitan komunikasi dan tidak adanya perwakilan yang ditunjuk dari kelompok disabilitas ini.

Penelitian selanjutnya disarankan untuk dilakukan dengan pendekatan berbeda dengan menyebarkan kuesioner kepada lebih banyak responden yang diklasifikasikan dalam kelompokkelompok berdasarkan jenis disabilitas. Hal ini akan membuat peneliti berikutnya dapat memetakan permasalahan aksesibilitas layanan transportasi secara lebih spesifik berdasarkan jenis disabilitas. Selain itu, penelitian berikutnya juga perlu melibatkan LSM terkait penyandang disabilitas serta pemerintah kota untuk mengkaji kebijakan kota inklusif, khususnya terkait layanan transportasi dari perspektif pemerintah. 


\section{UCAPAN TERIMA KASIH}

Peneliti mengucapkan terima kasih kepada organisasi Perkumpulan Penyandang Disabilitas Indonesia (PPDI) Aceh dan organisasi penyandang disabilitas lain yang terlibat dalam penelitian ini. Peneliti juga memberikan apreasiasi kepada Badan Perencanaan Pembangunan Daerah (Bappeda) Kota Banda Aceh yang telah membantu dalam fasilitasi pertemuan dengan organisasi penyandang disabilitas di Kota Banda Aceh.

\section{DAFTAR PUSTAKA}

[1] R. N. Singru, "Enabling Inclusive Inclusive Cities," Manila, Philippines, Dec. 2017. doi: 10.22617/TIM157428.

[2] F. Ndaumanu, "Hak Penyandang Disabilitas: Antara Tanggung Jawab dan Pelaksanaan oleh Pemerintah Daerah," J. HAM, vol. 11, no. 1, p. 131, Apr. 2020, doi: 10.30641/ham.2020.11.131150.

[3] A. Maftuhin, "Mendefinisikan Kota Inklusif: Asal-Usul, Teori dan Indikator," TATALOKA, vol. 19, no. 2, p. 93, May 2017, doi: 10.14710/tataloka.19.2.93-103.

[4] S. Thohari, "Pandangan Disabilitas dan Aksesibilitas Fasilitas Publik bagi Penyandang Disabilitas di Kota Malang," IJDSINDONESIAN J. Disabil. Stud. Vol 1, No 1 -, 2017, [Online]. Available: https://ijds.ub.ac.id/index.php/ijds/article/view/38.

[5] N. N. Sze and K. M. Christensen, "Access to urban transportation system for individuals with disabilities," IATSS Res., vol. 41, no. 2, pp. 66-73, Jul. 2017, doi: 10.1016/j.iatssr.2017.05.002.

[6] J. Beall and L.-H. Piron, "DFID Social Exclusion Review," London Sch. Econ. Polit. Sci. Overseas Dev. Inst., no. January 2005, p. 71, 2005, [Online]. Available: https://www.odi.org/sites/odi.org.uk/files/odi-assets/publications-opinion-files/2301.pdf.

[7] M. B. Santoso and N. C. Apsari, "Pergeseran Paradigma dalam Disabilitas," Intermestic J. Int. Stud., vol. 1, no. 2, p. 166, May 2017, doi: 10.24198/intermestic.v1n2.6.

[8] E. Hästbacka, M. Nygård, and F. Nyqvist, "Barriers and facilitators to societal participation of people with disabilities: A scoping review of studies concerning European countries," Alter, vol. 10, no. 3, pp. 201-220, Jul. 2016, doi: 10.1016/j.alter.2016.02.002.

[9] L. Sminkey, "World report on child injury prevention," Injury Prevention, vol. 14, no. 1. p. 69, 2008, doi: 10.1136/ip.2007.018143.

[10] C. Varghese, O. Oyere, M. Cowan, S. Davis, and B. Norrving, "World Health Organization," Stroke, vol. 47, no. 8, p. e210, 2016, doi: 10.1161/STROKEAHA.116.014233.

[11] UNESCO, "Kota inklusif," pp. 1-28, [Online]. Available: http://www.unesco.or.id/download/05_AssessmentTool_InclusiveCities_Bahasa_Rev281017B.pd f.

[12] E. Herawaty, M. Isya, and I. Caisarina, "Kajian Penyediaan Aksesibilitas Trotoar Untuk Penyandang Difabel Di Kota Banda Aceh Menurut Persepsi Masyarakat (Studi Kasus: Jalan Tgk. Daud Beureueh)," J. Tek. Sipil, vol. 4, no. 3, pp. 313-322, 2015.

[13] C. I. M Isya and Herawaty Etty, "Aksesibilitas Jembatan Penyeberangan Orang (Jpo) Bagi Penyandang Difabel Di Kota Banda Aceh Menurut Persepsi Masyarakat," Teras J., vol. 5, no. 1, 2015.

[14] M. Syafi'ie, "Pemenuhan Aksesibilitas Bagi Penyandang Disabilitas," INKLUSI, vol. 1, no. 2, p. 269, Jul. 2014, doi: 10.14421/ijds.010208.

[15] A.-M. Kissow, "Participation in physical activity and the everyday life of people with physical disabilities: a review of the literature," Scand. J. Disabil. Res., vol. 17, no. 2, pp. 144-166, Apr. 2015, doi: 10.1080/15017419.2013.787369. 